\title{
Embedding Explained Jury Verdicts in the English Criminal Trial
}

Mark Coen and Jonathan Doak*

University College Dublin and Nottingham Trent University

English juries do not provide reasons for their verdicts. This article argues that transparency is a fundamental value in modern decision-making, and that reform is needed to trial by jury so that verdicts are routinely accompanied by explanations. It examines the options that exist to incorporate explained verdicts in the English criminal trial and concludes that accountability and legitimacy would be enhanced through the use of a trained, independent lay facilitator to chair the deliberation process and draft an explained verdict.

\section{INTRODUCTION}

The notion of the unexplained verdict ${ }^{1}$ as a cornerstone of the English jury trial has been described as 'an article of constitutional faith' by one commentator. ${ }^{2}$ As with any article of faith, it must be scrutinised and justified. Such analysis has only begun in earnest in recent years, precipitated by the decision of the European Court of Human Rights in the case of Taxquet $v$ Belgium. ${ }^{3}$ This article argues that juries should always justify their verdicts and examines how this might be achieved. It begins by discussing the common law convention that jury verdicts are not accompanied by reasons. Historical and contemporary exceptions to the rule provide examples of instances in which English juries have provided information additional to the simple verdict. These examples rebut the argument that the common law jury is incapable of changing to become more accountable. The article proceeds to consider the benefits of introducing an explained verdict, before appraising options that might be adopted to achieve this reform. Our central premise is that jury verdicts have such major implications that they should be supported by cogent, publicly-available reasons in all cases.

\section{EXPLAINING THE UNEXPLAINED VERDICT}

It is widely known that the options available to contemporary juries are a general verdict of 'guilty' or 'not guilty'. ${ }^{4}$ As Lord Devlin observed:

\footnotetext{
$1^{*}$ The authors wish to acknowledge the kind assistance of Liz Campbell, John Jackson and Shane Kilcommins in commenting on previous drafts of this article. They also wish to thank the anonymous reviewers for their helpful comments.

The term 'unexplained verdict' will be used throughout this article to encapsulate the convention that jury verdicts are not accompanied by reasons. The phrase 'unreasoned verdict' is used in much of the literature, but the term 'unexplained verdict' is arguably clearer.

${ }_{2}$ P Roberts, 'Does Article 6 of the European Convention on Human Rights Require Reasoned Verdicts in Criminal Trials?' (2011) 11(2) Human Rights Law Review 213 at 216. See also Ex p Harrington [1884] TLR 435, where Stephen J stated that magistrates who had refused to grant a theatre licence 'were no more bound to give their reasons...than a jury were bound to give reasons for their verdict'. Ibid, p 437.

3 ECtHR 13 January 2009 and (2012) 54 EHRR 26 (Grand Chamber). The Taxquet decision is discussed below.

${ }_{4}$ In Scotland there is an additional verdict, namely 'not proven'. See P Duff, 'The Not Proven Verdict; Jury Mythology and

"Moral Panics"' (1996) Juridical Review 1. In 2016 the merits of this third verdict were debated in the Scottish media and the Scottish Parliament. See, for example, 'Bid to scrap "not proven” verdict from Scots courts fails', available at:
} 
Judges give their reasons, either so as to satisfy the parties or because they themselves want to justify their judgments...The jury just says yes or no. Indeed, it is not allowed to expand upon that and its reasons may not be inquired into. It is the oracle deprived of the right of being ambiguous. ${ }^{5}$

While some commentators have highlighted the dangers posed by the apparent unaccountability of the jury, ${ }^{6}$ this feature of the criminal justice process is largely unquestioned, as exemplified by Humphreys $\mathrm{J}$ in $R v$ Larkin $:^{7}$

In this country we consider that a jury is the best possible tribunal yet devised for deciding whether or not a man is guilty...but no one has ever suggested that a jury is composed of persons who are likely at a moment's notice to be able to give a logical explanation of how and why they arrived at their verdict. ${ }^{8}$

Williams characterised this statement as encapsulating 'the usual sentimental credentials' ${ }^{9}$ attributed to the jury. In Larkin the trial judge had asked the foreman of the jury on what basis the verdict of manslaughter had been returned. The Court of Appeal made it clear that juries should never be asked to explain their verdicts, unless the verdict itself is unclear. As will be seen, that principle has since been revisited by the Court of Appeal in the limited context of manslaughter verdicts.

Various rationales may be invoked to account for the non-provision of reasons by juries, with many lying deeply buried in the institution's history. The jury evolved from a body whose members had personal knowledge of the facts and which could gather evidence on its own motion to the disinterested fact-finder we know today. ${ }^{10}$ According to Jackson: 'So long as jurors acted on their own knowledge their verdicts could continue to be given a kind of oracular authority'. ${ }^{11}$ The proximity of the early jurors to the circumstances of the case imbued their decision with legitimacy and 'social accountability." ${ }^{12}$ Another historical factor for the unexplained verdict stems from the belief that jury verdicts were 'divinely inspired.' 13 Hence, it would be inappropriate to require justification of the God-directed outcome.

http://www.bbc.com/news/uk-scotland-scotland-politics-35659541 (accessed 24/1/2017).

${ }_{5}$ P Devlin, Trial by Jury (London: Methuen, 1966) pp 13-14.

${ }_{6}$ See eg, P Darbyshire, 'The Lamp That Shows That Freedom Lives - Is it Worth the Candle?' [1991] Crim LR 740 at 748 ; J

Frank, Law and the Modern Mind (Stevens \& Sons, 1949) 171-178; G Maher, 'The Verdict of the Jury' in M Findlay and P

Duff (eds) The Jury Under Attack (London: Butterworths, 1988) 40 at 44-45; R. J. O’Hanlon, 'The Sacred Cow of Trial by Jury’ (1990) 27 Irish Jurist 57 at 66; E R Sunderland, 'Verdicts, General and Special' (1920) 29(3) Yale LJ 253 at 258-260; G

Williams, The Proof of Guilt: A Study of the English Criminal Trial (London: Stevens \& Sons, 2nd edn, 1958$) 278$.

${ }_{7}$ R v Larkin [1943] KB 174.

${ }_{8}$ Ibid, p 176.

9 Williams, above n 6, p 277.

${ }_{10}$ See further D Klerman, 'Was the Jury Ever Self-Informing?' in M Mulholland and B Pullan (eds) Judicial Tribunals in England and Europe, 1200-1700 (Manchester: Manchester University Press, 2003) 58; M Macnair, 'Vicinage and the Antecedents of the Jury' (1999) 17(3) Law and History Review 537.

${ }_{11}$ J D Jackson, 'Making Juries Accountable' (2002) 50 American Journal of Comparative Law 477 at 490.

12 Ibid, p 529. 
The unexplained verdict may owe its existence to the perception that the process of arriving at a decision is produced by the 'feel' the jurors have for the case, and an acceptance that this may not be possible to articulate. A further rationale can be found in the notion of jury nullification, or 'jury equity', whereby jurors return a verdict which is contrary to the law or the evidence. The highly controversial ability of jurors to nullify, which is perceived by some as one of the safeguards of the accused and by others as an aberration whereby jurors place themselves above the law, ${ }^{14}$ is clearly facilitated by the non-provision of reasons. ${ }^{15}$

Whatever its precise origins, the unexplained verdict is closely related to the common law secrecy rule. That rule prevents disclosure or investigation of a jury's deliberations and would obviously be violated by the provision of reasons. In Ellis $v$ Deheer ${ }^{16}$ the judges of the Court of Appeal were unanimous that evidence could not be received of what transpired between jurors when considering their verdict, including the reasons for such verdict. While Bankes LJ decried any investigation of 'the reasons for [the jurors'] decision', ${ }^{17}$ Atkin LJ referred to the inadmissibility for any purpose of 'the grounds upon which the verdict was given. ${ }^{18}$ For His Lordship, the object of the rule was 'to protect the jurymen themselves and prevent their being exposed to pressure to explain the reasons which actuated them in arriving at their verdict'. ${ }^{19}$

The foregoing analysis indicates that it is impossible to identify a definitive historical cause for the convention that most jury verdicts are unaccompanied by reasons. In addition, judges and authors such as Lord Devlin have tended to accord this convention a status more akin to an absolute rule. The next section will demonstrate that such a viewpoint ignores the historical reality whereby jurors were not confined to the returning of simple verdicts devoid of further information.

\section{ILLUMNINATING VERDICTS - SOME OVERLOOKED DEVICES}

While the law has not required juries to give reasons, modern criminal justice discourse fails to reflect the fact that this rule was never absolute. Until the eighteenth century judges sometimes asked juries to provide the rationale for verdicts, particularly in instances in which they disagreed with the outcome. ${ }^{20}$ Such requests often preceded a direction from the judge

${ }_{13}$ A S Goldstein, 'Jury Secrecy and the Media: The Problem of Post-Verdict Interviews' (1993) University of Illinois Law Review 295 at 295 .

${ }_{14}$ For an overview of the harms and benefits of nullification see N S Marder, 'The Myth of the Nullifying Jury' (1999) 93 Northwestern University Law Review 877 at 926-943.

${ }_{15}$ T Brooks, ‘A Defence of Jury Nullification' (2004) 10(4) Res Publica 401 at 402.

$16[1922] 2$ KB 113.

${ }_{17}$ Ibid. p 118.

${ }_{18}$ Ibid, p 121. Warrington LJ agreed.

${ }_{19}$ Ibid. Other, more dubious rationales for the secrecy rule include the need for finality in respect of verdicts and the

preservation of confidence in the jury system. For a critique of these rationales, see J Jaconelli, Open Justice: A Critique of the Public Trial (Oxford: Oxford University Press, 2002) 235-262 and M McHugh, ‘Jurors’ Deliberations, Jury Secrecy, Public

Policy and the Law of Contempt' in Findlay and Duff, above n 6, p 56 and pp 62-67.

${ }_{20}$ C Allen, The Law of Evidence in Victorian England (Cambridge: Cambridge University Press, 1997) 3; J H Langbein, 'The Criminal Trial Before the Lawyers' (1978) 45(2) University of Chicago Law Review 263 at 289. 
for the jury to deliberate again. ${ }^{21}$ This practice appears to have vanished by the nineteenth century. By then, the role of the judge had evolved to police the application of the newlyemerging laws of evidence, rather than discussing the merits of individual cases with the jurors. ${ }^{22}$ Other mechanisms for the provision of insight into jury decision-making have also existed. These are significant in the context of the debate about jury accountability, because they demonstrate that elaboration upon the general verdict is not a foreign concept in England. Indeed, examples of explanations for verdicts can be found by reference to three particular devices: special verdicts, jury riders and explained verdicts in manslaughter cases.

One practice deviating from the general verdict of guilty or not guilty was the special verdict, which remained intact well into the twentieth century. Defined as 'a verdict in which the jury decided the facts but left the court to determine whether those facts gave rise to criminal liability', ${ }^{23}$ jurors could return a special verdict when they had 'doubts respecting any particular point of criminal law, ${ }^{24}$ and wanted to leave legal quagmires to the trial judge. The special verdict could also be an instrument of judicial control of juries in controversial trials, including seditious libel prosecutions ${ }^{25}$ and the infamous murder trial of $R v$ Dudley and Stephens ${ }^{26}$ The jury would be asked to determine a specific question or number of questions, with the judge formulating a general verdict informed by the answers. In England the special verdict is almost never used today; in $R v$ Solomon, ${ }^{27}$ it was stated that 'the jury cannot bring in a special verdict. The verdicts open to them are guilty or not guilty'. ${ }^{28}$ This view was echoed by Lord Hobhouse in $R v M i r z a^{29}$ : 'Under the common law system of jury trial, all findings of fact are to be made by the jury and it is ultimately their decision whether to convict the defendant. Special verdicts may not be asked for'.$^{30}$

A further means by which juries could provide information additional to the verdict was by issuing a rider. A rider consisted of an addendum to the verdict, detailing the jury's opinion on some aspect of the case. These were attached to verdicts on an ad hoc basis and were quite common, largely because an automatic sentence of death followed convictions for certain offences, (in the twentieth century, notably murder). The rider could highlight a particular issue such as the jury's views of the behaviour of the accused or the police. ${ }^{31}$ The use of riders declined steadily in the latter half of the twentieth century, to the extent that it is now almost unknown. An exception was the trial of the Earl of Hardwicke for supplying cocaine. The jury passed a note to the judge stating that it would have acquitted him if permitted by law. The peer had supplied the drug to an undercover newspaper reporter and

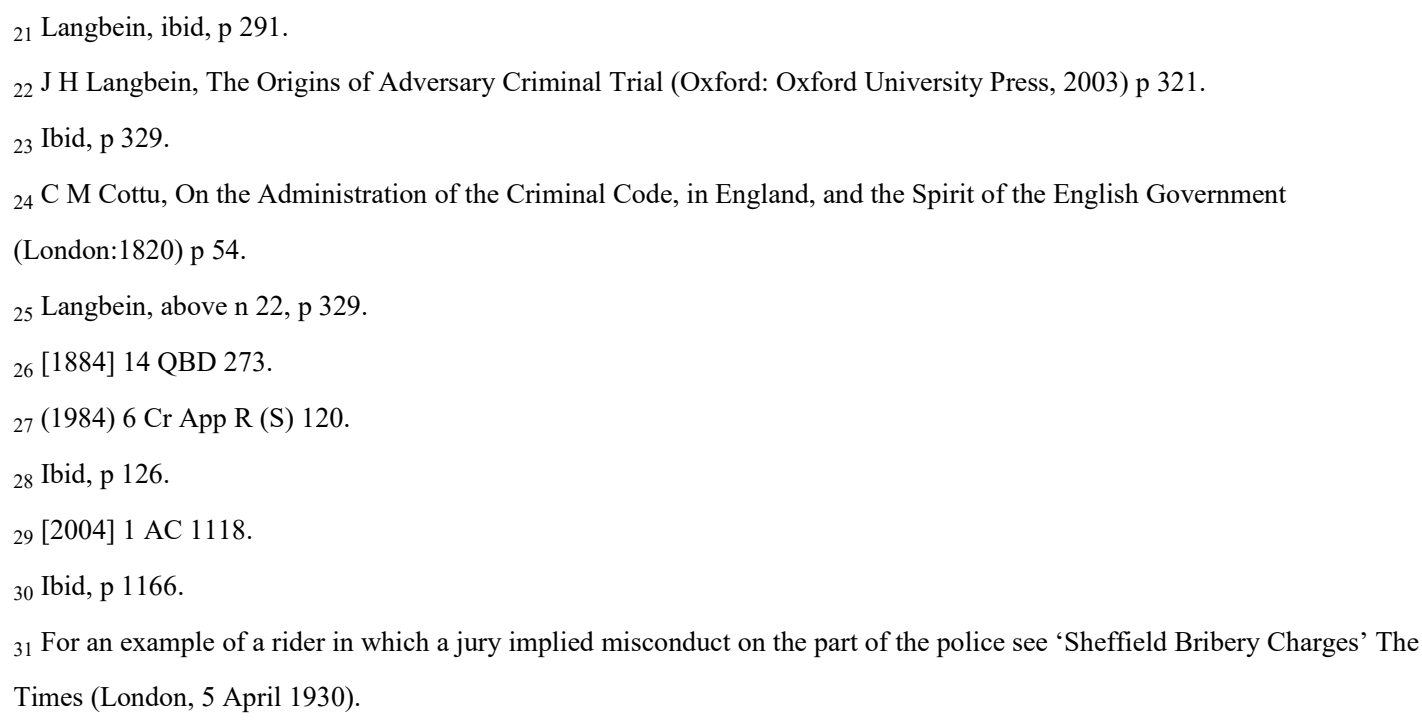


the jury described the use of such covert methods as 'extreme provocation'. ${ }^{32}$ Having regard to 'the jury's clearly stated views', ${ }^{33}$ the trial judge suspended Hardwicke's two-year sentence. In an unsuccessful appeal against conviction on the basis that the evidence against him was obtained through an abuse of process, counsel for Hardwicke referred to the rider 'as an indication that, to the minds of twelve well informed lay people, the investigatory procedure adopted here did amount to an affront to the public conscience' ${ }^{34}$ In the Scottish case of HM Advocate $v$ Tracey, ${ }^{35}$ Lord Uist referred to the ability of jurors to append riders, observing: 'It is not a practice which appears to have been subjected to any close analysis and it is one on which no authoritative guidance has been given'. ${ }^{36}$

Aside from riders, there is clear common law authority for the proposition that a judge may ask a jury to explain a manslaughter conviction where there are a number of potential factual bases for the verdict. In a particular case the verdict may be open to multiple interpretations; the jury might have found gross negligence, a lack of intention to kill or cause serious harm, or the presence of the reductive defences of loss of control or diminished responsibility. In $R v$ Cawthorne $e^{37}$ the Court of Appeal reviewed conflicting authorities as to whether juries should be questioned where the basis of a manslaughter verdict is uncertain, and held that this was entirely for the discretion of the trial judge. The exercise of this discretion would not be questioned on appeal, 'save in the most exceptional circumstances', ${ }^{38}$ on which the court did not elaborate.

The practice authorised by Cawthorne arguably involves a breach of the common law secrecy rule confirmed in $R v$ Mirza, ${ }^{39}$ which provides that judges cannot enquire into the deliberations of a jury after the verdict has been delivered. ${ }^{40}$ The relevance of the procedure to the present article is that although narrowly linked to the judicial sentencing function, it nevertheless illustrates that the aversion to asking juries for verdict explanations is not absolute.

The procedures outlined above indicate that it is wrong to conceive of the jury as a body forever confined to the limited vocabulary of 'guilty' and 'not guilty'. The article now builds on this analysis by considering the benefits of introducing explained verdicts, before evaluating a number of methods by which this might be accomplished.

\section{THE CASE FOR EXPLAINED VERDICTS}

Whilst the foregoing analysis reveals that certain forms of jury verdicts have not been entirely devoid of reasons, there is no doubt that the archetypal verdict at common law still tells us

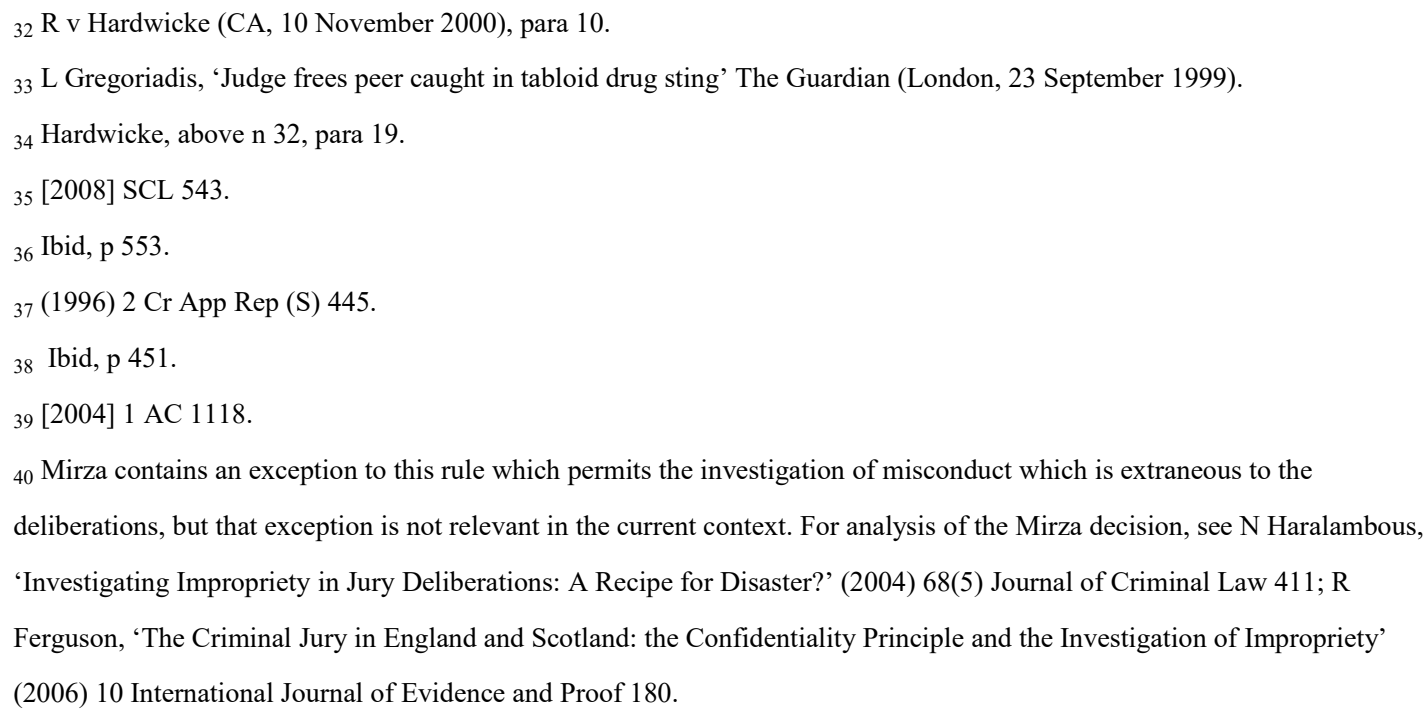


nothing about how or why the jurors reach their conclusions. Provided jurors act bona fide and do not engage in misconduct, ${ }^{41}$ their verdict is subject to little oversight. There are, however, questions about the long-term feasibility of retaining this approach. While the focus of this article is not squarely on the issue of jury nullification, where the jury disregards the law to reach what it regards as a fair outcome, ${ }^{42}$ it is important to acknowledge that our proposal for explained jury verdicts is informed by a perspective that regards such action by jurors as illegitimate and contrary to the law as formulated by parliament and the judiciary. If our model of explained verdicts were adopted, verdict reasons indicating that jurors had disregarded the law in arriving at that verdict would be a ground of appeal. We now turn to the arguments that we believe justify the introduction of explained verdicts.

The obvious consequence of decision-making without reasons is a lack of transparency. Transparency is strongly associated with the notions of both natural justice and a fair hearing since, without it, parties would be unable to protect their rights. ${ }^{43}$ As Lord Denning put it: 'The giving of reasons is one of the fundamentals of good administration'. ${ }^{44}$ Recently the notion of transparency has emerged as a core benchmark of good practice in relation to liberal criminal justice systems. In England and Wales, duties to provide reasons exist inter alia in the context of the arrest of a suspect; ${ }^{45}$ the refusal to grant bail; $;{ }^{46}$ the failure to proceed with certain prosecutions; ${ }^{47}$ the admission of bad character evidence at trial; ${ }^{48}$ the sentencing of an offender; ${ }^{49}$ and the referral of a case to the Court of Appeal by the Criminal Cases Review Commission. ${ }^{50}$ Critically for present purposes, magistrates must give reasons if they convict an accused. ${ }^{51}$ There is thus something intuitively anomalous about the presence

${ }_{41}$ For examples of jury misconduct, see Attorney General v Fraill (2011) 2 Cr App Rep 21; Attorney General v Pardon [2012]

EWHC 3402 (Admin); Attorney General v Dallas (2012) 1 Cr App R 32; Attorney General v Davey (2014) 1 Cr App R 1.

While jurors may be punished for such misconduct it is quite difficult to have a verdict set aside on the basis of alleged juror

misbehaviour. See above, n 40 .

${ }_{42}$ See above, n 14 and n 15 .

${ }_{43}$ It is a general principle of good practice across many different fields of public law that decisions which adversely affect

members of the public should always be accompanied by reasons. Although there is no general common law duty to give

reasons in English administrative law (see R (on the application of Hasan) v Secretary of State for Trade and Industry [2009] 3

All ER 539), such an obligation is widely found in statute and the common law has established many such individual duties: see generally P Craig, 'The Common Law, Reasons and Administrative Justice' (1994) 53(2) Cambridge Law Journal 282; M

Cohen, 'Reason-Giving in Court Practice: Decision-Makers at the Crossroads' (2007) 14 Columbia Journal of European Law

257. Under Article 296 of the Treaty of the European Union, all institutions are under an obligation to give reasons for all legal measures

${ }_{44}$ Breen v Amalgamated Engineering Union [1971] 2 QB 175 at 191.

${ }_{45}$ Police and Criminal Evidence Act 1984, s 28(3).

${ }_{46}$ Bail Act 1976, s 5(3)(a). In certain cases the granting of bail also carries a duty to provide reasons: s 5(2A).

${ }_{47}$ In R v DPP, ex p Manning [2001] QB 330 it was held that whilst the Director of Public Prosecutions was not under a general duty to provide reasons for a decision not to prosecute, it was reasonable to do so where no compelling grounds suggested otherwise. In circumstances where an individual had died whilst in the custody of the State and a properly directed inquest had reached a verdict of unlawful killing, reasons should have been given for a decision not to prosecute.

${ }_{48}$ Criminal Justice Act 2003, s 110.

${ }_{49}$ Criminal Justice Act 2003, s 174 as amended by the Legal Aid, Sentencing and Punishment of Offenders Act 2012, s 64(2).

${ }_{50}$ Criminal Appeals Act 1995, s 14(4).

${ }_{51}$ Criminal Procedure Rule 24.3(5)(a). 
of the unexplained jury verdict in the criminal justice system, and the lack of transparency raises three specific concerns: legitimacy, popular consent and the quality of justice.

Transparency is inextricably linked to the issue of legitimacy. Whilst transparency is increased through lay participation, it is also undermined by the secrecy surrounding deliberations ${ }^{52}$ and the lack of an explained verdict. Part of the jury's raison d'être is the legitimation of the criminal justice process through civic participation and democratisation; hence it has long been considered to act as a check against abuse of power by the state. ${ }^{53}$ However, the secret operation of the jury places it at odds with modern expectations of good decision-making, and threatens its status as a defender of rights. The New Zealand Law Commission recognised this in 2012, stating: 'Even if [jurors'] reasoning process cannot be faulted, the veil of secrecy leaves room for speculation that they were improperly influenced by irrelevant considerations and thus undermines public confidence in the outcome'. ${ }^{54}$

The secrecy rule attaching to jury deliberations serves very important functions including the encouragement of candid discussions in the jury room, the protection of jurors from pressure and the prevention of the publication of juror interviews and memoirs. However, it also restricts society's ability to assess the functioning of the jury system. Section 8 of the Contempt of Court Act 1981 on the disclosure of jury deliberations has been replaced by section 20D of the Juries Act 1974, which is worded in a similar way to its predecessor. It makes it an offence 'to disclose information about statements made, opinions expressed, arguments advanced or votes cast by members of a jury in the course of their deliberations in proceedings before a court, or...to solicit or obtain such information. ${ }^{55}$ While research conducted by Thomas suggests that the vast majority of jurors perform their duties diligently and lawfully, ${ }^{56}$ and demonstrates the wide variety of simulation and interview-based jury research that could be done within the confines of section 8 , the fact remains that jurors could not, and may not, be interviewed about their deliberations in real cases. Thomas argues that the interviewing of former jurors about their deliberations is not a useful methodology, because the answers are unlikely to be reliable, especially if an unfair consideration like the race of the accused has been a factor. ${ }^{57}$ Other academics dispute this, referring to the current impermissibility of asking those who have acted as jurors about the 'evidential factors, credibility assessments and factual assumptions ${ }^{58}$ that shaped the real trials that they participated in. The Law Commission recognised the potential value of this type of research in 2013, when it recommended that the law be amended to permit the interviewing of jurors about deliberations in actual cases for approved academic purposes $;{ }^{59}$ a recommendation that was not acted upon by Parliament. The ban on

\footnotetext{
${ }_{52}$ For discussion of the jury secrecy rule see McHugh, above n 19; Jaconelli, above n 19.

${ }_{53}$ J Jackson, 'Judicial Responsibility in Criminal Proceedings' (1996) 49 Current Legal Problems 59 at 90 . See further T

Brooks, 'The Right to Trial by Jury’ (2004) 21(2) Journal of Applied Philosophy 197; F Davis, 'The Jury as a Political

Institution in an Age of Counterterrorism' (2013) 33(1) Politics 5; H L Ho, 'Liberalism and the Criminal Trial' (2010)

32 Sydney Law Review 269.

${ }_{54}$ New Zealand Law Commission, Alternative Pre-Trial and Trial Processes: Possible Reforms (Issues Paper 30, 2012 ) 24.

${ }_{55}$ Juries Act 1974, s 20D as inserted by s 74(1) Criminal Justice and Courts Act 2015.

${ }_{56}$ C Thomas, Are Juries Fair? (London: Ministry of Justice, 2010).

${ }_{57}$ C Thomas, "Exposing the Myth" (2013) Counsel 25 at 26.

${ }_{58}$ The quotation is taken from the views expressed by Professors Ellison and Munro to the Law Commission. Law

Commission, Contempt of Court (1): Juror Misconduct and Internet Publications (2013) p 97.

${ }_{59}$ Ibid, p 102.
} 
certain types of properly-conducted inquiry, embodied in the current law, strengthens the case for explained verdicts.

The acceptance of jury verdicts, based on their perceived legitimacy, depends on social consent. Such consent derives from the belief that procedures that are just and proper ought to be followed. ${ }^{60}$ Without popular consent, law and policy risk being undermined and contested. ${ }^{61}$ The institution of the jury has enjoyed widespread popular support. ${ }^{62}$ However, in an age where the accountability of public institutions is expected and valued, ${ }^{63}$ increased public debate about the role of the jury, combined with future negative press coverage, could diminish public confidence in the institution. Over the years there has been considerable debate as to whether juries should try certain types of cases. ${ }^{64}$ There have also been a number of widely reported cases involving jury misconduct, ${ }^{65}$ which prompted a Law Commission report and the enactment of offences to deal with jurors who behave improperly. ${ }^{66}$ Juror incompetence has also been flagged as a potential issue in the press; in February 2013 there was widespread negative media coverage in relation to a list of apparently bizarre questions posed by the jury to the judge in the highly publicised trial of Vicky Pryce for perverting the

${ }_{60}$ See M Zelditch, 'Processes of Legitimation: Recent Developments and New Directions' (2001) Social Psychology Quarterly 4.

${ }_{61}$ T R Tyler, 'Procedural Justice, Legitimacy, and the Effective Rule of Law' in M Tonry (ed) Crime and Justice: A Review of Research, Volume 30 (Chicago: University of Chicago Press, 2003) p 283.

${ }_{62} \mathrm{~J}$ Roberts and M Hough, Public Opinion and the Jury: An International Literature Review (London: Ministry of Justice Research Series 1/09, 2009) pp 12-19.

${ }_{63}$ Jackson, 'Making Juries Accountable', above n 11, pp 486-487.

${ }_{64}$ There has been considerable debate over the past three decades in relation to the capacity of juries to try complex fraud cases. See for example, R Auld, Review of the Criminal Courts of England and Wales (London: HMSO, 2001) 200-204; Fraud Trials Committee Report (London: HMSO, 1986) paras 8.47-8.51; Royal Commission on Criminal Justice (London: HMSO, 1993) pp 136-137; Juries in Serious Fraud Trials: A Consultation Document (London: Home Office 1998); R F Julian, 'Judicial Perspectives on the Conduct of Serious Fraud Trials' [2007] Crim LR 751. Section 43 of the Criminal Justice Act 2003, which was repealed by section 113 of the Protection of Freedoms Act 2012, would have permitted the prosecution to apply for a trial without a jury in fraud trials.

${ }_{65}$ See for example, 'Inquiry into “use of Ouija Board” by Jurors' The Independent (24 June 1994); U Khan, 'Juror Dismissed from a Trial after Using Facebook to Help Make a Decision’ The Daily Telegraph (24 November 2008); J Taylor, ‘Juror Jailed for Contempt After Jetting Off to Malta' The Independent (5 April 2011); A Hough, ‘Juror in Facebook Contempt Prosecution after "Contacting Defendant During Trial”" The Daily Telegraph (13 June 2011); 'Juror, 19, Jailed for Halting Trial to Visit Theatre’ The Guardian (22 December 2011); O Bowcott, 'Juror Jailed over Online Research’ The Guardian (24 January 2012). See further C Thomas, 'Avoiding the Perfect Storm of Juror Contempt' [2013] Crim LR 483. ${ }_{66}$ See Law Commission, above n 56, and Part 3 of the Criminal Justice and Courts Act 2015. 
course of justice. ${ }^{67}$ Although incompetent or unethical practice likely occurs in a small minority of cases, the reporting of such instances underlines the need for greater transparency.

In addition to countering this risk of lowering public confidence, explained verdicts may be supported on the basis that they might bolster the quality of justice, insofar as they would serve as a process check on jurors becoming more readily exposed to extraneous material, particularly via the Internet. ${ }^{68}$ Coupled with increasingly relaxed evidentiary rules concerning the forms of evidence that can be presented at trial, ${ }^{69}$ as 'input' control on the trial declines, so the need for a greater degree of 'output' control arises:

The more relaxed the evidentiary standards become, however, with ever less probative and more potentially prejudicial evidence entrusted into the jury's care (albeit under evidentiary instruction), the more an adversarial deficit is likely to emerge in terms of the parties' ability to challenge how exactly such evidence was handled in the closed confines of the deliberation room. ${ }^{70}$

As Jackson argues, explained verdicts may enhance the overall quality of justice in that they might 'ensure that no adversarial deficit is created by any unreasoned verdict that emerges. ${ }^{71}$ Defendants and victims would thereby be provided with the reassurance that, even if they are displeased with the outcome, the trier of fact conducted itself diligently and acted in accordance with the law. ${ }^{72}$ Moreover, knowing the basis for the decision would assist both the defence and prosecution in understanding the range of appeal

${ }_{67}$ The jury was discharged after failing to agree a verdict. The trial judge stated that the questions asked by the jurors demonstrated 'absolutely fundamental deficits in understanding': F Hamilton, 'Pryce Trial Collapses Amid Doubt over Jury' The Times (21 February 2013). The case led to considerable debate in the national media. See for example, R Sabey, 'Pryce Retrial after Jury Farce' The Sun (21 February 2013); M Phillips, 'Do we Need IQ Tests for Juries? Vicky Pryce Trial has Exposed a Breathtaking Level of Ignorance and Stupidity’ The Daily Mail (21 February 2013); E Branagh, 'Stupid Jurors cause Vicky Price Retrial' The Daily Star (21 February 2013). For an academic perspective, see S Lubet and K Chang, 'Stupid Juror Questions?' 37 American Journal of Trial Advocacy 315.

${ }_{68}$ Law Commission, above n 56; J Jackson, 'Unbecoming Jurors and Unreasoned Verdicts: Realising Integrity in the Jury Room' in D Dixon, J Hunter, P Roberts and S Young (eds) Integrity in Criminal Process (Oxford: Hart, 2016) p 281.

${ }_{69}$ Recent examples of a relaxation in evidentiary controls are contained in the Criminal Justice Act 2003, which provided for a major erosion of the rule against hearsay and the more widespread admissibility of character evidence.

70 Jackson, 'Unbecoming Jurors', above n 66, p 301.

71 Ibid.

${ }_{72}$ While defendants might well be the primary beneficiaries of explained verdicts, it is arguable that victims ought to be able to exercise a similar 'right to know' or 'right to truth' within the criminal justice system. This would be a reflection of wider trends concerning the expansion of victims' rights in human rights and transitional justice settings and arguably builds on the 'right to information' contained in Articles 3-7 of European Directive 2012/29/EU establishing minimum standards on the rights, support and protection of victims of crime. See further J Doak, 'Enriching Trial Justice for Victims of Crime: Lessons from Transitional Environments' (2015) 15(2) International Review of Victimology 139-160. 
options that may be available, ${ }^{73}$ which was expressly recognised by the Strasbourg Court in Murray $v U K:^{74}$

[I]n Northern Ireland, where trial judges sit without a jury, the judge must explain the reasons for the decision to draw inferences and the weight attached to them. The exercise of discretion in this regard is subject to review by the appellate courts. ${ }^{75}$

In the absence of an explained decision, appellate courts faced with arguments that particular verdicts are perverse or inconsistent with each other engage in a somewhat unreal exercise which purports to identify the reasoning of the jury. In the words of Dyson LJ: 'Since juries do not give reasons for their verdicts...the interpretation of their verdicts often involves what might be termed "speculation"". ${ }^{76}$ As Lord Steyn acknowledged in Mirza, maintaining the position of 'we shall never know' does not sit easily alongside modern conceptions of fairness and due process in the criminal justice system. ${ }^{77}$ However, as the law stands, an appeal court cannot interfere on the basis of perversity or inconsistency as long as 'it is possible to postulate a rational line of reasoning, ${ }^{78}$ in the verdicts given. The threshold which must be crossed before the Court of Appeal will quash a verdict in such cases has been described as 'a very high hurdle'. ${ }^{79}$ An appellant must persuade the Court of Appeal that the inconsistency between verdicts can only be explained by confusion or a wrong approach to the evidence on the part of the jury ${ }^{80}$ The absence of an explanation by the jury of different verdicts on similar counts contributes significantly to the severity of this threshold, and allows the perception of unfairness or arbitrariness to flourish.

\section{A RIGHT TO AN EXPLAINED VERDICT?}

Notwithstanding these arguments, there was, until recently, little consideration of the need for reform of the unexplained verdict. However, the issue became very prominent in the aftermath of the decision of the Second Section of the European Court of Human Rights in Taxquet $v$ Belgium. ${ }^{81}$ Here the applicant complained that his right to a fair trial under Article 6 of the European Convention on Human Rights had been violated because the jury had failed to give reasons for its decision to convict the defendant of murder. Article 337 of the Belgian Criminal Code provided for a 'structured verdict' whereby the presiding judge submitted a list

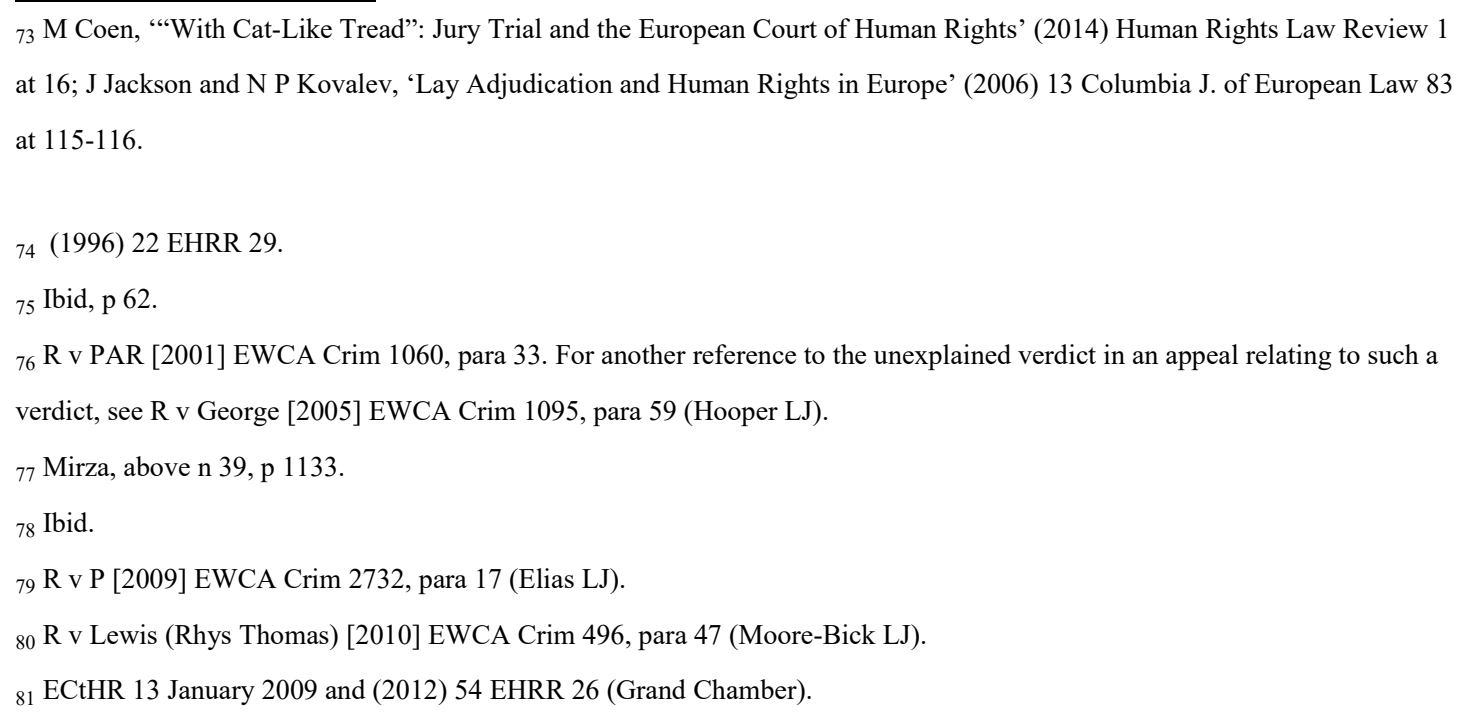


of formal questions, based on the text of the indictment, to which the panel of nine lay jurors had to give answers. Thus, in Taxquet's case, a total of 32 questions were posed by the judge which largely concerned the core elements of murder and attempted murder, and to which the jury responded with monosyllabic 'yes' or 'no' answers.

Taxquet's complaint was upheld by the Court on the basis that 'such laconic answers to vague and general questions could have left the applicant with an impression of arbitrary justice lacking in transparency'. ${ }^{82}$ The bottom line, essentially, was that the defendant was unable to understand the reasoning behind the verdict which was of vital importance since such reasons would be the basis upon which he decided to accept the verdict or consider an appeal. Given the centrality of the jury system to a number of European jurisdictions, and the hitherto apparent dismissal of previous arguments relating to the provision of reasons, ${ }^{83}$ the Taxquet decision sent ripples of unease around a number of signatory states, with fears that both the common law jury and its continental counterpart ${ }^{84}$ could be under threat. The Belgian decision to pursue an appeal before the Grand Chamber was unsurprising, as were the third party interventions of the governments of the United Kingdom, Ireland and France. ${ }^{85}$

The decision of the Grand Chamber, delivered in November 2010, upheld the ruling of the Court against Belgium, but also gave some measure of relief to those who had feared, by implication, that the common law jury model might also be under threat. It affirmed that the Convention does not require jurors to give reasons for their decision and that Article 6 does not preclude a defendant from being tried by a lay jury even where reasons are not given for the verdict' ${ }^{96}$ This was subject to other safeguards being observed:

Such procedural safeguards may include, for example, directions or guidance provided by the presiding judge to the jurors on the legal issues arising or the evidence adduced... and precise, unequivocal questions put to the jury by the judge, forming a framework on which the verdict is based or sufficiently offsetting the fact that no reasons are given for the jury's answers... Lastly, regard must be had to any avenues of appeal open to the accused. ${ }^{87}$

The Grand Chamber proceeded to state that the nature of the questions posed to the jury in Taxquet's case were inadequate to such an extent that the applicant would have been unable to understand why he was found guilty. ${ }^{88}$ The decision may have prompted a collective sigh of relief among supporters of the jury and policymakers in common law jurisdictions, since, from a legal perspective, the earlier approach in Saric v Denmark ${ }^{89}$ seems to have prevailed, namely that carefully crafted judicial directions and summing up serve to offset the absence of an explained verdict. The Grand Chamber's characterisation of these features of a criminal

\footnotetext{
${ }_{82}$ ECtHR 13 January 2009, para 63. 
trial as transparency safeguards has been criticised..$^{90}$ They do not provide insights into why a particular verdict has been reached, which was the core problem identified by the Grand Chamber in Taxquet's case. As Lippke asserts, even if a formal right to an explained decision cannot be located in law, "it is hardly a stretch to see such a requirement as an implication of the moral right to trial' ${ }^{91}$ This, he argues, means that guilty verdicts by juries ought to be justified by clear and adequate reasons.

\section{TOWARDS A FRAMEWORK FOR EFFECTIVE DELIBERATION}

It seems that the Taxquet litigation - coupled with increased academic debate on the issue has prompted efforts to formulate a more coherent framework as to how juries conduct their fact-finding role. In England and Wales there have been changes in the ways that judges direct juries, with a tendency for judges to offer written directions in addition to the oral guidance. ${ }^{92}$ Auld L.J. had recommended something akin to this in his 2001 report. ${ }^{93}$ In 2010 the Judicial Studies Board endorsed the practice of trial judges providing jurors with a written 'route to verdict', essentially amounting to a flowchart or question-based decision-tree to aid their deliberation process. ${ }^{94}$ A study conducted by Cheryl Thomas in 2012-13 found that 70 per cent of the jurors surveyed had received written directions from the judge, with every juror reporting that they found these helpful. ${ }^{95}$ Route to verdict aids may assist the jury in navigating the complexity of the interface between legal rules and the fact-finding process, particularly in those cases where 'there are several possible bases for conviction, or several possible offences, or defences to consider'. ${ }^{96}$ Their usefulness is emphasised in The Crown Court Compendium ${ }^{97}$ and the Criminal Practice Directions. ${ }^{98}$ In his Review of Efficiency in Criminal Proceedings, ${ }^{99}$ Sir Brian Leveson recommended the use of such aids in all cases, not merely those with particularly complex facts or aspects of law:

${ }_{90}$ Coen, above n 71, p 19.

${ }_{91}$ R L Lippke, 'The Case for Reasoned Criminal Trial Verdicts' (2009) 22(2) Canadian Journal of Law and Jurisprudence 313 at 318 (emphasis added).

${ }_{92}$ N Madge, ‘Summing Up: A Judge's Perspective’ [2006] Crim LR 817 at 821-822. Judges are expressly empowered under the Criminal Procedure Rules 2014 to give directions and questions in writing: Crim PR r 38.14(3).

${ }_{93}$ Auld, above n 62, p 172.

${ }_{94}$ Judicial Studies Board, Crown Court Bench Book: Directing the Jury (2010).

95 Thomas, ‘Avoiding', above n 63, p 497.

${ }_{96}$ R v Thompson (2010) 2 Cr App Rep 27 at 267.

${ }_{97}$ Judicial College, The Crown Court Compendium Part 1: Legal Summaries, Directions and Examples (2016), available at: https://www.judiciary.gov.uk/wp-content/uploads/2016/05/crown-court-compendium-pt1-legal-summaries-directionsexamples-20160511.pdf (accessed 24/1/2017), pp 1-7 - 1-9.

${ }_{98}$ The Criminal Practice Directions 2015 Amendment No 1 [2016] EWCA Crim 97 states: 'Save where the case is so straightforward that it would be superfluous to do so, the judge should provide a written route to verdict. It may be presented (on paper or digitally) in the form of text, bullet points, a flowchart or other graphic.'

99 B Leveson, Review of Efficiency in Criminal Proceedings (2015), available at: https:/www.judiciary.gov.uk/wpcontent/uploads/2015/01/review-of-efficiency-in-criminal-proceedings-20151.pdf (accessed 24/1/2017). 
The Judge should devise and put to the jury a series of written factual questions, the answers to which logically lead to an appropriate verdict in the case. Each question should be tailored to the law as the Judge understands it to be and to the issues and evidence in the case. These questions - the 'route to verdict' - should be clear enough that the defendant (and the public) may understand the basis for the verdict that has been reached. ${ }^{100}$

The second sentence is problematic because it repeats the sleight of hand relied upon by the Grand Chamber in Taxquet itself, namely the equation of jury directions and transparent jury decision-making. Although the provision of steps to verdict aids may assist the jury in arriving at the verdict, it falls far short of an explained verdict in that there is no means of ascertaining how or why the jury reached its decision. Thus the deliberation process remains closed in the sense that neither defendants nor the public are given a window into the reasons underlying the jury's determination. In our view, there is a strong normative case for introducing a more transparent form of explained verdict into the criminal trial and the section that follows will consider how this might be done.

\section{MODELS FOR THE PROVISION OF REASONS}

The most obvious, and perhaps efficient, means of embedding explained verdicts in criminal trials would be to abolish juries and transfer the responsibility of making decisions as to guilt, accompanied by reasons, to professional judges. This juryless approach is relatively commonplace in Europe, and has been used in Ireland and Northern Ireland with the Special Criminal Court and the 'Diplock' Courts respectively. In 2012 the New Zealand Law Commission suggested that juries be replaced by panels consisting of one judge and two jurors, who would deliberate together and provide reasons for their verdicts. One consideration underpinning this proposal was the fact that the current lay jury does not provide reasons. ${ }^{101}$ However, the jury retains a high level of popular support, ${ }^{102}$ and the right to trial by jury is rightly valued as fundamental legal right which should not be readily dispensed with. Working therefore from the premise that lay participation is generally something that ought to be enhanced rather than restricted in the criminal justice system, we now consider different ways in which some form of explained verdict might be incorporated in the common law legal framework. To this end, we will appraise three options for reform: (a) recording deliberations; (b) adopting a mixed panel approach; and (c) lay facilitation.

\section{(a) Recording deliberations}

One of the most straightforward, if radical, means to ascertain the reasons underlying verdicts would be to install a recording facility within the jury room. This could be done by a simple voice recorder, a camera or even through the use of a traditional stenographer. Such an arrangement would have the immediate effect of eradicating any pretence that the content of discussions would remain secret. Whilst eavesdropping on the jury has long been prohibited 100 Ibid, $\mathrm{p} 79$.

${ }_{101}$ New Zealand Law Commission, above n 52, p 26.

${ }_{102}$ Roberts and Hough, above n 60, pp 12-23. 
under the common law, ${ }^{103}$ it formed part of an infamous experiment within a federal district court in Kansas in 1954 as part of the Chicago Jury Project. ${ }^{104}$ The recording had the consent of the trial judges, but not the jurors. On coming to light, the practice was subject to widespread condemnation and a spate of legislative activity to ban the recording of jury deliberations followed. ${ }^{105}$ In the half century that followed, there was little appetite for a repeat exercise, although in 1997 CBS, a major commercial US network, broadcast a documentary containing actual jury deliberations from four criminal trials in Arizona. ${ }^{106}$

Whilst a number of American commentators have argued for the recording of deliberations, ${ }^{107}$ the notion has never been seriously entertained in England and Wales, given the assault it would represent on the secrecy of the jury room. In 2002, Robertshaw proposed what he termed an 'ethical bugging procedure' whereby jurors would give their consent to the possibility of their deliberations being recorded, but would not know if they were in fact being recorded. ${ }^{108}$ Despite the well-documented difficulties in combating juror misconduct in the internet age, ${ }^{109}$ Robertshaw's suggestion essentially advocates the use of a sledgehammer to crack a nut. Such an approach would undermine the very rationale on which jury trial is based, namely the judgment of one's peers without state interference. The prospect that 'Big Brother' was always listening, or indeed that defendants might be able to access the recordings, would almost certainly lead to deliberations becoming formulaic and unimaginative, and potentially limit the candour of juror contributions. This article does not therefore consider the recording of deliberations to be a viable reform which should be pursued, in order to explain verdicts or for any other reason.

\section{(b) The mixed tribunal}

An alternative approach would be to introduce a form of collaborative court, whereby one or more professional judges would cross the threshold to join lay members and form a panel

${ }_{103}$ Whilst section 9 of the Contempt of Court Act 1981 expressly prohibits recording in court precincts in England and Wales, the secrecy rule can be traced back to the eighteenth century. See J Hunter, 'Jury Deliberations and the Secrecy Rule: The Tail that Wags the Dog?' (2013) 35 Sydney Law Review 809.

104

The project appeared in print as H Kalven and H Zeisel, The American Jury (Little, Brown and Co 1966) ${ }_{105}$ See S Kassin and L Wrightsman, The American Jury on Trial: Psychological Perspectives (New York: Hemisphere, 1988) pp 13-14; S S Diamond and N Vidmar, 'Jury Room Ruminations on Forbidden Topics' (2001) 87(8) Virginia Law Review 1857 at 1867.

${ }_{106}$ See W R Bagley, 'Jury Room Secrecy: Has the Time Come to Unlock the Door?’ (1999) 32 Suffolk University Law Review 481 at $486-488$.

${ }_{107}$ See T Lewis, 'Toward a Limited Right of Access to Jury Deliberations' (2006) 58 Federal Communications Law Journal 195 at 207-211; C H Ruprecht, 'Are Verdicts, Too, Like Sausages?: Lifting the Cloak of Jury Secrecy’ (1997) 146 University of Pennsylvania Law Review 217 at 241-250.

${ }_{108}$ See P Robertshaw, 'For Auld Land Syne - Towards the Demise of the Jury' (2002) 66(4) J of Criminal Law 338 at 351352. The recording of deliberations to facilitate the investigation of misconduct has been suggested by other commentators also. See Ferguson, above n 40, pp 207-208.

109 See for exmple, E Brickman, J Blackman, R Futterman and J Dinnerstein, 'How Juror Internet Use has Changed the American Jury Trial' (2008) 1(2) Journal of Court Innovation 287; N Haralambous, 'Educating Jurors: Technology, the Internet and the Jury System' (2010) 19(3) Information and Communications Technology Law 255. See also Thomas, 'Avoiding', above $\mathrm{n} 63$. 
which would deliberate on the question of guilt. This would sidestep the difficulty of judges having to draft lengthy question lists and juries having to formulate a response. One of the professional judges would assume responsibility for drafting the verdict, along with a summary of the reasons for the decision. This practice evolved to become relatively commonplace across Europe in the nineteenth century, although three separate variations of the collaborative approach have been identified by Jackson and Kovalev. ${ }^{110}$

First, there is the German Schöffengericht model, whereby a professional judge is joined on the bench by two lay judges. The Schöffen hold the same full judicial status as the professional judges and can outvote them on questions of either fact or law. ${ }^{111}$ It is, however, for the professional judge alone (even if outvoted) to draft the judgment of the majority. This will contain a list of reasons for the verdict, which may include comments on the weight of the evidence and the credibility of witnesses. ${ }^{112}$ Adopted in many German-speaking countries, as well as certain Scandanavian and Eastern European jurisdictions, the precise composition may vary, as may the type of offence for which it is used and the possible sentences that may be passed. ${ }^{113}$ An alternative is the French model, which is distinctive owing to its high ratio of lay jurors to professional judges; the Cours d'Assises operates with three professional judges and nine lay members. In this setting the lay members do not formally join the bench, but retire to deliberate with the professional judges. Like the German model, the court is collectively responsible for questions of law and fact, and lay judges may outvote their professional colleagues. However, in contrast to the German model, the President of the Court prepares questions for the jury that are generally straightforward, factually oriented, and may be answered by yes or no responses. Deliberations take place in secret, with anonymous voting on each question posed. The presiding judge then announces the verdict in open court, and reveals whether the jury voted (by two-thirds majority) 'yes' or 'no' in response to each of the questions. ${ }^{114}$ The third variation recognised by Jackson and Kovalev is the 'expert assessor model' whereby certain lay professionals with expertise in a given area join the judges so that their knowledge or experience might enhance the quality of the decisionmaking process. Common in France and Germany, they share some similarities with the former institution of the English special jury ${ }^{115}$ and generally offer some form of justification for their verdicts. Auld LJ also envisaged some role for this form of tribunal in the English criminal justice system, whereby defendants in serious and complex fraud cases would be given a choice of a trial by judge alone, or a judge sitting with two lay experts. ${ }^{116}$

One could argue that each of the variations of the collaborative model combines the advantages of pure lay juries with those of trial by judge or judges alone. Lay persons usually comprise the majority of such tribunals, thereby preserving the advantages traditionally associated with the common law jury. In acting as a bulwark against excessive state authority, the involvement of lay people may serve to enhance the legitimacy of the verdict. It may also

${ }_{110}$ Jackson and Kovalev, above n 71, pp 94-95.

111 M. Bohlander, Principles of German Criminal Procedure (Oxford: Hart, 2012) 50.

112 Ibid. A sample judgment is contained in Annex 2 of Professor Bohlander's book: ibid, p 290.

${ }_{113}$ Jackson and Kovalev, above n 71, p 97.The authors note that while the total number of judges may vary, the number of lay

judges must always exceed the number of professional judges by one.

114 V P Hans and C M Germain, 'The French Jury at a Crossroads' (2011) 86 Chicago-Kent Law Review 737 at $756-757$.

115 See J Oldham, 'Special Juries in England: Nineteenth Century Usage and Reform' (1987) 8(2) Journal of Legal History 148.

${ }_{116}$ Auld, above n 62, pp 213-214. This suggestion was not acted upon by Parliament. 
improve the quality of the deliberation process, since lay members may inject a wide range of social values and professional experiences, which may counteract more limited or casehardened attitudes in the professional judiciary. In addition, the presence of professional judges might ensure that mixed juries would follow the law rather than their emotions, and would not rush their decisions. ${ }^{117}$ The contribution of professional triers of fact would also be helpful in drafting meaningful and articulate reasons for the verdict, which would add to public confidence in criminal trials. ${ }^{118}$ However, collaborative panels are lacking in one of the fundamental qualities of Anglo-American jury trial, namely that the decision-making process should rest with lay persons alone. Although it has been suggested that the likely ratio of any such mixed panel (of 12 lay persons to one professional judge) may counterbalance this concern, ${ }^{119}$ there remains a risk that it may be perceived as a 'court of nodders' ${ }^{120}$ Indeed, there is evidence to suggest that, as professional elites who possess a certain status, judges tend to dominate collaborative deliberations, with lay members assuming a back seat role. ${ }^{121}$ The fact remains that the nature and extent of likely judicial influence in collaborative decision-making is an unknown quantity, whereas the pure lay model at least ensures that all communications between the state (in the guise of the judge) and the trier of fact are open to public scrutiny. ${ }^{122}$ For that reason, the adoption of a mixed panel method, while in many ways an attractive means of embedding explained verdicts in criminal trials, would be unlikely to carry sufficient legitimacy in the common law world. It therefore does not represent a sustainable method of introducing explained verdicts.

\section{(c) Lay facilitation}

In a paper published in 2012, Catriona Murdoch mooted the idea of using oath-bound lay persons as 'jury monitors', who would observe deliberations to ensure that no extraneous material was introduced. ${ }^{123}$ However, arguably there is a wider role that might usefully be performed by lay persons; they could undertake a much more active role in assisting juries in drawing up coherent and articulate explanations for their verdicts. Lay facilitators are widely used within so-called 'citizens' juries', which are increasingly commonplace beyond the context of the criminal trial throughout the United Kingdom, Australia and parts of continental Europe. The concept involves assembling stakeholders within a local community to deliberate around matters of public administration that affect them, ranging from local planning and environmental issues, the prioritisation of budgets, and the organisation of healthcare and education. ${ }^{124}$ Essentially, the process revolves around the assumption that high quality information and intensive, yet structured, deliberation can generate consensus on a

${ }_{117}$ J E Dudzinski, ‘Justification for Juries: A Comparative Perspective on Models of Jury Composition' (2013) University of Illinois Law Review 1625 at 1639.

${ }_{118}$ It is also possible, however, that an overly legalistic approach to drafting reasons could actually serve to render the verdict more obscure and less accessible to the wider public.

${ }_{119}$ P Fitzpatrick, 'The British Jury: An Argument for the Reconstruction of the Little Parliament' (2010) 6 Cambridge Student Law Review 1 at 11 .

${ }_{120}$ N P Kovalev, 'Lay Adjudication of Crimes in the Commonwealth of Independent States: An Independent and Impartial Jury or a "Court of Nodders?"” (2004) 11(2/3) Journal of East European Law 123.

${ }_{121}$ S K Ivkovic, 'Exploring Lay Participation in Legal Decision-Making: Lessons from Mixed Tribunals' (2007) 40(2) Cornell International Law Journal 429 at 440-443.

122 V P Hans, 'Jury Systems Around the World' (2008) 4 Annual Review of Law and Social Science 275 at 290.

${ }_{123}$ C Murdoch, 'The Oath and the Internet'” (2012) 176 (11) Criminal Law and Justice Weekly 149. 
particular issue among a diverse group of individuals. ${ }^{125}$ The mechanics of a typical English citizens' jury have been described in the following terms:

A citizens' jury brings together a group of approximately 12-16 citizens, selected to be representative of the local community, to consider an issue in depth (usually over 3-5 days). The jury are fully briefed and hear information from and question expert witnesses, before discussing the issue amongst themselves. They then draw up their conclusions, facilitated by a trained moderator. A jury is not used to make binding decisions, but to advise or make recommendations about a policy. ${ }^{126}$

For present purposes, it can be noted that that the conclusions drawn up by citizens' juries are 'designed to explain the jury's judgements and recommendations'. ${ }^{127}$ Despite discernible differences in their operational context, there is considerable overlap between criminal juries and citizens' juries in terms of how they are assembled and how they are expected to perform. ${ }^{128}$ One key difference relates to deliberations. For their part, criminal jurors are often unsure how to structure their deliberations. ${ }^{129}$ Forepersons tend to be chosen after a very short space of time, with relatively little discussion of the strengths and weaknesses of a particular individual or their suitability for the role. ${ }^{130}$ Studies have also revealed that forepersons and other perceived 'high ranking' members of groups take a greater proportion of turns in speaking, often dominate discussions, and tend to be more influential over the verdict. ${ }^{131}$ Though large-scale studies have been rare, there is some evidence to suggest that the quality of deliberation quality tends to be high, and is characterised by thorough,

${ }_{124}$ For an overview see P McLaverty, 'Is Deliberative Democracy the Answer to Representative Democracy's Problems? A

Consideration of the UK Government's Programme of Citizen Juries' (2009) 45(4) Representation 379; A Coote and J

Lenaghan, Citizens' Juries: Theory into Practice (London: Institute for Public Policy Research 1997).

${ }_{125}$ J Gastil, P E Deess, P J Weiser and C Simmons, The Jury and Democracy: How Jury Deliberation Promotes Civic

Engagement and Political Participation (Oxford: Oxford University Press, 2010) p 180.

${ }_{126}$ Department of Enterprise, Transport and the Regions, Modernising Local Government: Local Democracy and Community Leadership (London: HMSO, 1998), para 4.12.

${ }_{127}$ G Smith and C Wales, 'Citizens' Juries and Deliberative Democracy' (2000) 48(1) Political Studies 51 at 59. There has been criticism that the conclusions of citizens' juries are sometimes not made publicly available: McLaverty, above $\mathrm{n} 122$, $\mathrm{p}$ 382.

${ }_{128}$ L Carson and R Lubensky, 'Citizens' Juries Pave the Way to the Law Courts' (2008) 33(1) Alternative Law Journal 10 at 11.

${ }_{129}$ V P Hans and N Vidmar, Judging the Jury (Perseus Publishing 1986) p 102. In an English study which interviewed people who had experienced jury service $67 \%$ of them stated that jurors should be given more information about how to conduct deliberations: Thomas, above n 54, p 39. This finding was discussed by Lord Judge in R v Thompson (2010) 2 Cr App Rep 27 at 266 .

${ }_{130}$ See D J Devine, L D Clayton, B B Dunford, R Seying, and J Pryce, 'Jury Decision Making: 45 Years of Empirical Research on Deliberating Groups' (2001) 7(3) Psychology, Public Policy and Law 622 at 697; L Ellison and V Munro, 'Getting to (not) Guilty: Examining Jurors' Deliberative Processes in, and Beyond, the Context of a Mock Rape Trial' (2010) 30(1) Legal Studies 74 at 88-89; S S Diamond and J D Casper, 'Blindfolding the Jury to Verdict Consequences: Damages, Experts, and the Civil Jury’ (1992) 26 Law and Society Review 513 at 547.

${ }_{131}$ Devine et al, ibid, p 696; R Hastie, S Penrod and N Pennington, Inside the Jury (Harvard University Press 2002 ) p 28. 
evidence-driven debates. ${ }^{132}$ However, in a larger study exploring data obtained from jurors and legal professionals associated with 179 criminal trials in Indiana, Devine et al found that the overall quality was variable. Juries often performed well in terms of understanding their instructions and reviewing the evidence, but problems arose in relation to securing equal input from all members, adopting an evidence-driven deliberation style, and avoiding factionalism. ${ }^{133}$ While the available evidence is mixed, it seems somewhat anomalous that an institution charged with such an important civic responsibility is free to undertake its deliberation process in an unfettered manner without any oversight mechanism in place. By contrast, the deliberations of citizens' juries are organised to be a fair, transparent and inclusionary process based around

judicious argument, critical listening, and earnest decision making...full deliberation includes a careful examination of a problem or issue, the identification of possible solutions, the establishment or reaffirmation of evaluative criteria, and the use of these criteria in identifying an optimal solution. ${ }^{134}$

The responsibility for overseeing the deliberation falls to a group facilitator who, unlike the foreperson of a criminal jury, will usually be trained to encourage members to articulate their individual views, deal with information in a systematic and rigorous way, and find common ground in evaluating it. ${ }^{135}$ In a systematic review of criminal jury decision-making studies from 1955 to 1999, covering some 206 empirical studies, Devine et al concluded that high quality deliberation was dependent on the presence of certain procedural criteria, namely:

(a) thorough review of the facts in evidence, (b) accurate jury-level comprehension of the judge's instructions, (c) active participation by all jurors, (d) resolution of differences through discussion as opposed to normative pressure, and (e) systematic matching of case facts to the requirements for the various verdict options. ${ }^{136}$

In an effort to ensure that these criteria are present, insofar as possible, throughout the deliberation process, criminal juries might also make use of a trained facilitator, in the same way as citizens' juries. This facilitator would join jurors in their deliberations, and their role would be limited to overseeing and assisting the deliberative process and authoring the reasons for the verdict at the end of the deliberation. He or she would have a basic knowledge of the core elements of law and procedure, but would also be

${ }_{132}$ S S Diamond, N Vidmar, M Rose and L Ellis, 'Inside the Jury Room - Evaluating Juror Discussions during Trial' (2003)

87 Judicature 54; S S Diamond, B Murphy and M Rose, 'Kettleful of Law in Real Jury Deliberations: Successes, Failures, and Next Steps' (2012) 106 Northwestern University Law Review 1537; J Gastil, S Burkhalter and L W Black, 'Do Juries Deliberate? A Study of Deliberation, Individual Difference, and Group Satisfaction at a Municipal Courthouse' (2007) 38 Small Group Research 337.

${ }_{133}$ J D Devine, J Buddenbaum, S Houp, D P Stolle and N Studebaker, 'Deliberation Quality: A Preliminary Examination in Criminal Juries' (2007) 4(2) Journal of Empirical Legal Studies 273 at 288.

${ }_{134}$ J Gastil, Democracy in Small Groups: Participation, Decision Making, and Communication (New Society 1993 ) p 22. ${ }_{135}$ See further, K N Dillard, 'Envisioning the Role of Facilitation in Public Deliberation' (2013) 41(3) Journal of Applied Communications Research 217.

${ }_{136}$ Devine et al, ‘Jury Decision Making', above n 128, p 707. 
familiar with group dynamics and evidence-based decision-making. ${ }^{137}$ As Darbyshire et al note in their 2001 meta-analysis, '[i]f there is one point upon which nearly every commentator agrees it is that juries have a great deal of difficulty understanding and applying judicial instructions. ${ }^{138}$ To this end, the facilitator could also act as a conduit between the jurors and the court, clarifying any aspects of written instructions or a 'route to verdict' that had been issued. He or she could also encourage clear and articulate decisionmaking by ensuring that only the relevant material facts are considered and that the law is properly applied.

The main strength of involving a facilitator in the deliberations is that it would allow an explained verdict to be issued with the guarantee that it had been reached without the presence of the trial judge in the jury room. This form of verdict could inspire confidence and a sense of procedural fairness in defendants, complainants and the wider public. Whilst, for present purposes, the key advantage is likely to be the capacity of the facilitator to assist in the provision of reasons, other benefits would also follow. A trained outsider could help structure discussions, rending them more efficient yet more rigorous. Likewise, he or she could safeguard against the risks of 'groupthink', ${ }^{139}$ domination of the process by certain individuals, and could also act as a safeguard against collective bias and various forms of misconduct. ${ }^{140}$ Given these improvements to the quality of the process, it is also suggested that the quality of the outcome would be similarly enhanced, with a greater chance that the verdict itself would be accurate.

While the use of trained facilitators is unknown in respect of criminal juries, their use is not uncommon within the criminal justice system as a whole. Within mediation and alternative justice settings, facilitators are regularly used to ensure that the discussion is structured, coherent, inclusive and fair, whilst 'ownership' of the process is said to rest with the parties themselves. ${ }^{141}$ Indeed, effective facilitation is often regarded as a key benchmark of success in the evaluation of restorative justice programmes. ${ }^{142}$ A myriad of questions would need to be addressed in terms of how to give effect to such a radical change to jury decision-making. One option would be for courts to draw up lists of approved facilitators who would either be employed directly by H.M. Courts \& Tribunals Service or provide services as freelancers. While the cost implications of a professionalised pool of facilitators may be significant, consideration could be afforded to training volunteers to undertake the role. ${ }^{143}$

${ }_{137}$ See further, S Shelton, 'Jury Decision Making: Using Group Theory to Improve Deliberation’ (2006) 34(4) Politics and Policy 706.

${ }_{138}$ P Darbyshire, A Maughan and A Stewart, What can the English legal system learn from jury research published up to 2001 ? (London: Kingston Business School/Kingston Law School, Kingston University, 2002) p 25. See also Thomas, above n 54, who found that two-thirds of jurors surveyed stated that they would have liked more information on conducting deliberations ( $\mathrm{p}$ 39).

${ }_{139}$ See further, D H Mitchell and D Eckstein, 'Jury Dynamics and Decision-Making; A Prescription for Groupthink' (2009)

1(1) International J. of Academic Research 163.

${ }_{140}$ It is also possible that a particular juror, group of jurors or the accused, could intimidate the facilitator. However, comprehensive training, along with an appropriate oversight mechanism, could help to offset this risk.

${ }_{141}$ J Braithwaite, Restorative Justice and Responsive Regulation (Oxford: Oxford University Press, 2002$)$ p 145.

${ }_{142}$ J Braithwaite, 'Setting Standards for Restorative Justice' (2002) 42(3) British Journal of Criminology 563 at 574. 
The prospect of opening the doors of the jury room to an outsider would undoubtedly attract considerable dissent. The key objection would most likely revolve around the concern that someone who was not party to the trial would then be placed in a position where he or she could influence the jurors. It would require a statutory reversal of the long-standing common law rule in Goby $v$ Weatherill, ${ }^{144}$ which states that the presence of any non-juror during deliberations requires that the verdict be vitiated. The risk of undue influence, even unintentional, ought not to be dismissed lightly. However, it may be suggested that the status quo is even more conducive to undue influence, given the above-noted tendency of 'high ranking' members of the group to dominate the decision-making process.

Once a verdict had been agreed, we propose that the facilitator would lead the jurors in the drafting of a narrative verdict outlining why the jury arrived at its conclusion on each count. These need not be detailed, but ought to present an outline as to why the jury accepted or rejected each element of the offence/defence. Both parties would then be given the opportunity to make representations to the trial judge, who would then review the reasons to ensure that sufficient detail was given and that the law was followed. Inadequate expressions of reasons could then be returned to the jury to be reformulated. This aspect of the process would not be unproblematic since, as Jackson reminds us, jurors are not required to reach a verdict according to the law; rather they are bound to determine the case on the merits in accordance with the evidence. ${ }^{145}$ There is thus a clear risk that reasons which are determined by the trial judge to be legally inadequate, or poorly rationalised, may actually be factually adequate in the eyes of the jury. Such judicial oversight may erode the jury's ability to inject 'lay acid' into a professionalised and legalistic arena, ${ }^{146}$ which is one of the fundamental rationales for the existence of the jury system in its current form. Moreover, the publication of reasons would most likely lead to the creation of new grounds of appeal, namely that the jury had failed to apply the law correctly or had not complied with its duty to provide reasons. ${ }^{147}$ To some extent, these concerns might be minimised through the issuing of robust judicial guidelines, though undoubtedly the strength of the jury as a form of 'governance' may be eroded. Ultimately, however, any such decline in the political power of the jury would be offset by the introduction of greater transparency in the performance of its core function of determining innocence and guilt. ${ }^{148}$

In summary, we concede that the introduction of a facilitator is not without potential problems. However, of the three options outlined above, this proposal seems best suited to maintaining most of the advantages of the lay jury while bringing its decision-making processes into line with contemporary standards of accountability and legitimacy.

${ }_{143}$ Volunteers are already widely used by the Witness Service across England and Wales (see further R Mawby, 'Public Sector Services and the Victim of Crime' in S Walklate (ed), Handbook of Victims and Victimology (Cullompton: Willan, 2007) p 209. Many mediation and restorative justice schemes across continental Europe also rely heavily on volunteer facilitators. See F Dünkel, P Horsfield and A Parosanu (eds) European Research on Restorative Juvenile Justice: Volume I Research and Selection of the Most Effective Juvenile Restorative Justice Practices in Europe: Snapshots from 28 EU Member States (Brussels: International Juvenile Justice Observatory, 2015).

144 [1915] 2 KB 674.

${ }_{145}$ Jackson, 'Making Jurors Accountable', above n 11, p 523.

${ }_{146}$ Z Bankowski, 'The Jury and Reality' in Findlay and Duff, above n 6, p 20.

${ }_{147}$ Lippke, above n 90, p 316.

148 Jackson, 'Unbecoming Jurors', above n 66, p 301. 


\section{CONCLUSION}

It is clear that the "oracular verdict ${ }^{149}$ of the jury is safe for the foreseeable future, both under the domestic law of England and, perhaps more crucially, under the European Convention on Human Rights. This should not, however, be the end of the matter. Auld perhaps overstates the advantages of an explained verdict and underplays the ability of 'determined and sufficiently conspiratorial ${ }^{150}$ jurors to hide misconduct or prejudice behind carefully constructed reasons. Nevertheless, he makes persuasive arguments about the need for the jury to embrace accountability and so adapt to the norms of the modern world. In particular, the incorporation of reasons, acknowledged by the law as beneficial in a myriad of contexts, could be achieved with a little creativity and a willingness to modernise. The provision of reasons might cause jurors to put more thought into their deliberations. It might also highlight irregularities in some, if not all, of the cases in which they occur.

While we argue that explained verdicts represent a worthy reform, questions remain in relation to its precise parameters and content. It is unclear, for example, whether reasons ought to be given in circumstances of guilt, or innocence, or in both scenarios; what should happen in the event that jurors agree on an outcome but not on the reasons; and the nature and extent of the common law secrecy rule that would remain intact. ${ }^{151}$ Unease has also been voiced that such a move would spell the end of the political role of the jury as a buttress against the abuse of state power, as well as increasing the workload of both trial judges and the Court of Appeal, and endangering the finality of the verdict. ${ }^{152}$ These concerns are certainly not without foundation but, in our view, are issues that are ultimately of less importance than the overarching need to improve the accountability of the jury.

Certain supporters of the jury are perhaps guilty of underestimating its ability to evolve and adapt over time, as demonstrated by the reaction of governments and commentators to the Second Section decision and the submissions of states to the Grand Chamber in Taxquet. As Lord Devlin stated, the jury has been constructed 'biologically rather than mechanically'. ${ }^{153}$ Just as jurors in the past used an array of devices to explain their verdicts, a range of options exist that should be actively considered in order to ensure the jury's continued legitimacy as a core democratic institution.

\footnotetext{
${ }_{149}$ Auld, above n 62, p 168.

150 Ibid. p 537.

${ }_{151}$ See further M Csere, 'Reasoned Criminal Verdicts in the Netherlands and Spain: Implications for Juries in the United

States' (2013) 12 Connecticut Public Interest Law Journal 415 at 434; Jackson, above n 11, pp 520-522.

${ }_{152}$ On these and other potential drawbacks of explained verdicts, see Lippke, above n 90, pp 323-330.

${ }_{153}$ Devlin, above n 5, p 57.
} 